УДК 686.12.056

\title{
ТРАНСПОРТНО-ПЕРЕДАВАЛЬНІ ПРИСТРОЇ \\ КНИЖКОВО-ЖУРНАЛЬНИХ БЛОКІВ У пОтОКОвОМУ вИРОБНИЦтвІ
}

\section{() А. І. Іванко, к.т.н, доцент, П. П. Шостачук, магістрант, НТУУ «КПІ», Київ, Україна \\ В статье рассмотрены основные способы и средства транспортировки книжных и журнальных блоков в поточном производстве.}

In the article considered basic methods and facilities of transporting of book and magazine blocks are in a line production.

\section{Постановка проблеми}

Технологічні процеси переміщення, зміни напрямку руху, зміни орієнтації в просторі та перебазування книжковожурнальних блоків широко використовуються у потокових лініях (ПЛ), блокообробних агрегатах (БА), вкладально-швейнорізальних агрегатах (ВШРА), машинах для обрізування блоків з трьох боків (ТРМ), машинах незшивного скріплення (МHC), підбиральних машинах (ПМ), машинах для розрізування блоків двійників (МРД) та ін.

У потоковому виробництві книжково-журнальних блоків (КЖБ) транспортувальна система відповідає за необхідну точність позиціювання книжкових блоків з однієї секції обробки в іншу. Від вибору транспортувального пристрою для переміщення блока з однієї позиції в іншу, залежить якість виконання усіх наступних технологічних операцій.

Технологічні операції обробки КЖБ виконуються під час вистою та під час переміщення напівфабрикатів. Так виконання процесу обрізування КЖБ з трьох боків в традиційних ТРМ відбувається при кроковому переміщенні транспортувальної системи, а підготовка корінця до нанесення клею в МКС безупинним способом. Можливе використання транспортерів лінійної, конвеєрної або карусельної побудови $[1,2]$.

Через технічну та технологічну складність процесу вистійного обрізування, для збільшення продуктивності доводиться встановлювати в потокові лінії пристрої для розмежовування блоків на дві або три гілки з подальшим їх обрізуванням на триножових різальних машинах. Однак ТРМ безупинного типу суттєво підвищують продуктивність ПЛ, і пристрої для переміщення КЖБ з однієї секції в іншу не задовольняють заданим швидкісним характеристикам [3].

\section{Аналіз попередніх досліджень}

Відомий диференціально-зубчастий механізм, який забезпечує передачу блока з однієї різальної секції в другу. Проміжкові 
транспортери розміщені під кутом 90․ До складу механізму входять чотири каретки, що встановлені на важелях пазового кулачкового механізму. Привод зубчастих коліс забезпечує механізму частоту обертання каретки $\mathrm{n}=1$ об/с., або П = 4 бл/с. [4-6].

Даним механізмом забезпечується передача блока в наступну секцію без зміни його орієнтації в просторі. Синхронізація швидкості роботи механізму з проміжковими пасовими транспортерами забезпечується загальним приводом машини.

Зміна напрямку переміщення блоків, без зміни його орієнтації у просторі, може відбуватися за рахунок кулачково-коромислового та кулачкового зі штовхачем механізмів. Синхронізація даних механізмів 3 пасовими транспортерами дозволяє каретці підтримувати заданий режим роботи. Приводяться в дію механізми від головного привода машини.

Змінити напрямок блока пропонується за рахунок механізмів дво-кривошипного чотириланника. Каретка з блоком змінює напрямок переміщення на 90 за рахунок двох кривошипів і шатуна.

Відомі схеми механізмів для зміни напрямку переміщення блока за допомогою зубчастопасових транспортерів. Жорстко закріплена каретка елементами транспортера має можливість рухатися по напрямних. Вони одночасно відповідають за надійне фіксування блока. Синхронізація руху проміжкових транспортерів і кареток забез- печується за рахунок загального привода машини. При зміні кроку переміщення блоків в проміжкових транспортерах передбачене регулювання відстані між каретками.

\section{Мета роботи}

Мета даної роботи - проведення порівняльного аналізу способів та пристроїв, що забезпечують зміну напрямку руху або перебазування книжковожурнальних блоків під час їх транспортування. Аналіз технологічних факторів, що сприяють збільшенню продуктивності потокового виробництва.

\section{Результати проведених досліджень}

Книжковий блок переміщуючись з однієї технологічної операції обробки в іншу, змінює своє положення і напрямок руху. Розробляються і впроваджуються у серійне виробництво фірмами-виробниками («Kolbus», «Muller Martini», «Perfecta», «Wohlenberg») оригінальні конструкції пристроїв та механізмів для зміни напрямку руху КЖБ (таблиця).

Напрямок руху блоків може змінюватися на $90^{\circ}$ або на $180^{\circ}$ зі зміною, або без зміни орієнтації у просторі. Зміна базування чи напрямку руху блока може відбуватися у нефіксованому положенні (знаходитись у вільному стані), або фіксуватися у транспортуючих ланках (затискачі, каретки, тракові транспортери, пасові транспортери).

Нефіксоване положення характерне транспортувальній секції ТРМ стрічкового типу, що оснащується накопичувальним 


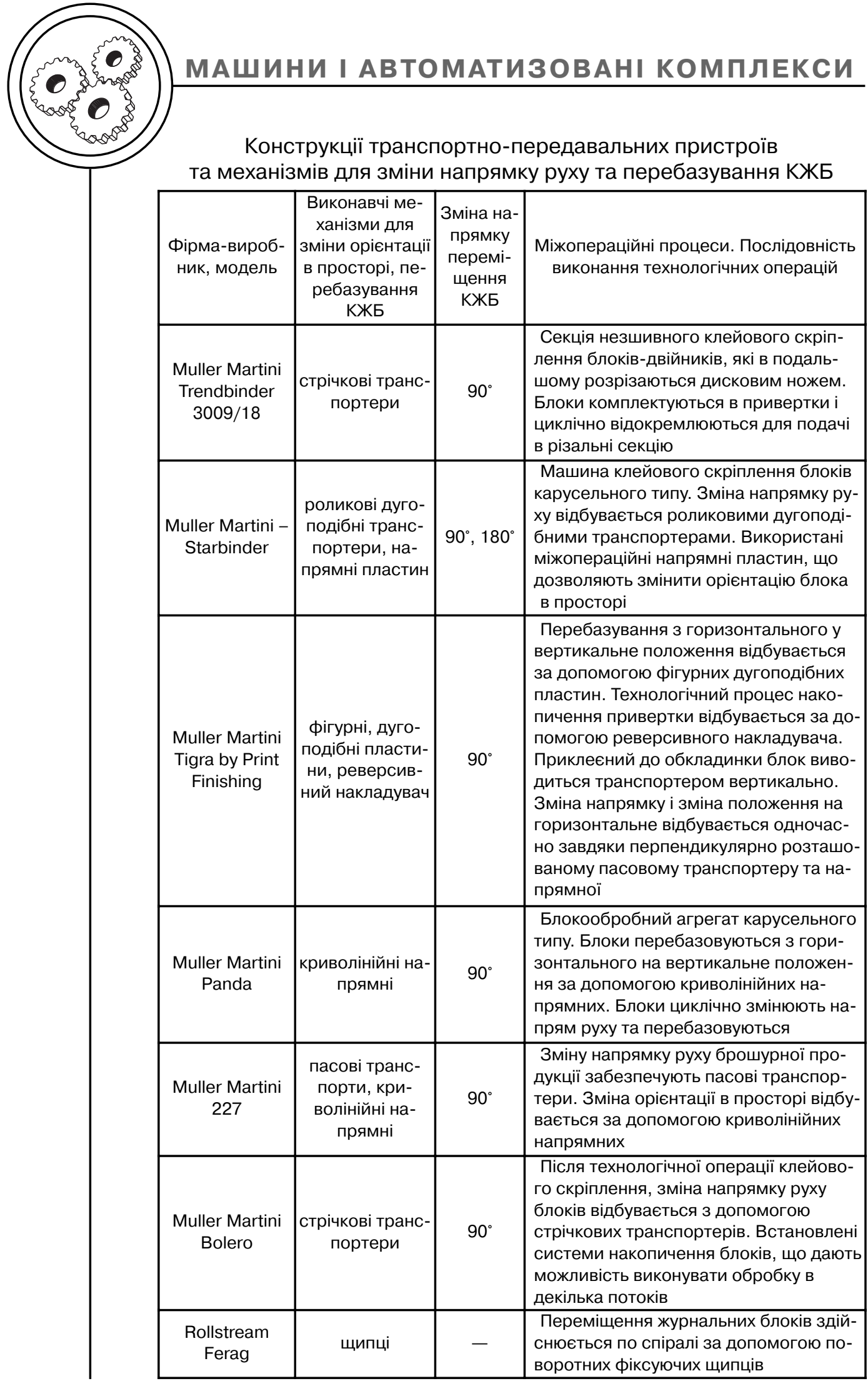


Закінчення табл.

\begin{tabular}{|c|c|c|c|}
\hline $\begin{array}{l}\text { Фірма-вироб- } \\
\text { ник, модель }\end{array}$ & $\begin{array}{l}\text { Виконавчі ме- } \\
\text { ханізми для } \\
\text { зміни орієнтації } \\
\text { в просторі, пе- } \\
\text { ребазування } \\
\text { КЖБ }\end{array}$ & $\begin{array}{c}\text { Зміна на- } \\
\text { прямку } \\
\text { перемі- } \\
\text { щення } \\
\text { КЖБ }\end{array}$ & $\begin{array}{c}\text { Міжопераційні процеси. Послідовність } \\
\text { виконання технологічних операцій }\end{array}$ \\
\hline Ferag EasySert & щипці & - & $\begin{array}{l}\text { Переміщення КЖБ виконується з до- } \\
\text { помогою щипців. Застосована поштуч- } \\
\text { на ковшова схема переміщення жур- } \\
\text { налів. Зміна руху не обмежується од- } \\
\text { ним напрямком, передбачене одно- } \\
\text { часне перебазування напівфабрикатів }\end{array}$ \\
\hline $\begin{array}{c}\text { Kolbus } \\
\text { Industrial Book } \\
\text { Production }\end{array}$ & каретки & $90^{\circ}$ & $\begin{array}{l}\text { Машина для виготовлення книг в па- } \\
\text { літурці. Всі процеси побудовані за лі- } \\
\text { нійним принципом. Пристроями за- } \\
\text { безпечується перебазовування та ци- } \\
\text { клічне обертання напівфабрикатів у } \\
\text { вертикальній площині }\end{array}$ \\
\hline $\begin{array}{l}\text { Kolbus Binder } \\
\text { Line }\end{array}$ & $\begin{array}{c}\text { роликова дуго- } \\
\text { подібна систе- } \\
\text { ма, напрямні } \\
\text { пластини }\end{array}$ & $90^{\circ}, 180^{\circ}$ & $\begin{array}{l}\text { Лінія клейового скріплення блоків ка- } \\
\text { русельного типу. Використані пристрої } \\
\text { зміни напрямку руху, що мають роли- } \\
\text { кову дугоподібну будову. Забезпечу- } \\
\text { ється зміна орієнтації блока в просторі } \\
\text { за допомогою напрямних пластин }\end{array}$ \\
\hline $\begin{array}{l}\text { Kolbus Perfect } \\
\text { Binder }\end{array}$ & $\begin{array}{c}\text { роликова дуго- } \\
\text { подібна систе- } \\
\text { ма, напрямні } \\
\text { пластини }\end{array}$ & $90^{\circ}, 180^{\circ}$ & $\begin{array}{l}\text { Машина клейового скріплення блоків } \\
\text { карусельного типу. Застосовані прист- } \\
\text { рої зміни напрямку руху роликової ду- } \\
\text { гоподібної будови. Використані меха- } \\
\text { нізми, що дозволяють змінити орієн- } \\
\text { тацію блока в просторі за допомогою } \\
\text { напрямних пластин }\end{array}$ \\
\hline $\begin{array}{c}\text { Stahl VBF } \\
\text { EH+EP casing } \\
\text { in machine }\end{array}$ & каретки & $90^{\circ}, 180^{\circ}$ & $\begin{array}{l}\text { Блокообробна машина для виготов- } \\
\text { лення книг в палітурці. } \\
\text { Використані механізми перебазуван- } \\
\text { ня блоків, та зміни їх орієнтації в про- } \\
\text { сторі }\end{array}$ \\
\hline
\end{tabular}

магазином. Зміна напрямку руху блока на $90^{\circ}$ із зміною його орієнтації у просторі забезпечується циклічним поштучним виведенням кареткою або ланцюговою передачею з упорами.

Широко використовуються різноманітні конструкції роликових (гвинтових) транспортерів. Вони одночасно з'єднують два стрічкових транспортери та забезпечують необхідний напрямок руху блоків.
В конвеєрах блокообробних агрегатів блоки переміщуються по замкнутому ланцюгу, який складається із ланок-затискачів. В різальних секціях ланказатискач отримує траєкторію за рахунок напрямних. Взаємодія напрямних і роликів забезпечує почерговий поворот книжкового блока на $90^{\circ}$ навколо горизонтальної осі під час проходження з однієї різальної секції в іншу. 
Спроектований і запропонований до впровадження у виробництво компанією Muller Martini механізм зміни напрямку руху книжкових блоків [Patent United States US 2011/0054672 A1. Arrangement for the timed processing of a printed product with the aid of a transfer device. Robert W.MCFARLAND. Assignee: Muller Martini Holdings AG-Filed: 03.09.2009; Pub.Date: 03.03.2011 Patent Application Publication MCFARLAND et al. - 20 pages]. Механізм сконструйований у вигляді хрестовини, на кінцях якої встановлені чотири системи захоплення блоків. В подальшому блок переміщується на $90^{\circ}$ для передачі на наступну технологічну операцію. За один оберт головного вала механізм дозволяє перемістити чотири блоки.

Відома інша схема механізму зміни напрямку руху на 90 із збереженням орієнтації блока в просторі. Механізм має планетарну будову та п'ять систем захоплення блоків, що розташовані 3 кроком 72. Дана конструкція забезпечує динамічне балансування пристрою, що суттєво впливає на плавність роботи механізму в цілому та на якість транспортування книжкових блоків.

Зміна орієнтації блока в просторі забезпечується механізмом, сконструйованим у вигляді зірочки з 5-ма каретками, кут між якими $72^{\circ}$ [Patent United States US 2010/0086379 A1. Method and arrangement for producing perfect bound book blocks. Daniel Langenegger. Assignee: Muller Martini Holdings AG-Filed: 2.10.2010; Pub. Date: 08.04.2010. Patent Application Publication Langenegger et al. - 13 pages].
В процесі обробки, блок змінює своє початкове горизонтальне положення на вертикальне з подальшою зміною напрямку руху на 90 градусів.

Розроблені безупинні способи обрізування КЖБ з трьох боків та пристрої, що дозволяють працювати на технологічних швидкостях транспортування блока $\mathrm{V}_{\text {Б. }}>2 \mathrm{M} / \mathrm{c}$. Технологією передбачається обрізування з трьох боків у двох секціях. Тобто, як варіант, у першій секції, проводиться обрізування передка блока, а в другій - головки і хвостика. При їх використанні в потокових лініях, процеси вирівнювання, позиціювання та подачі книжкового блока в наступну секцію обробки відбуваються безупинно.

Пристрої повинні забезпечувати відмінну точність виконання технологічних операцій при відносно високих технологічних швидкостях. Крім того, зберігається можливість переналагодження виконавчих органів пристрою для зміни формату.

Вибір транспортно-передавальних пристроїв книжковожурнальних блоків в потоковому виробництві залежить від наступних ознак:

- конструкції секції безупинного обрізування;

- фізико-механічних характеристик КЖБ та їх геометричних розмірів;

- траєкторії і закону періодичного руху виконавчих органів;

- напрямку переміщення або орієнтації в просторі;

- способу транспортування (вертикальне - корінцем вниз або уверх; горизонтальне корінцем вперед або назад). 
секцію.

- кроку подачі в різальну

Транспортно-передавальні пристрої тракового типу за конструкцією є відносно складними. Для переналагодження системи на інший формат, витрачається значний час на визначення необхідного зусилля затиску блока (p), залежно від його фізикомеханічних характеристик $(\mathrm{k}, \alpha)$.

У передавальних пристрояхзатискачах, деформація блока $\varepsilon=\left(\sigma^{1 / k} / \alpha\right)$ не $\epsilon$ визначальною. Оскільки напруження стиску блока $(\sigma)$ регулюється конструктивними особливостями каретки.

Транспортувальна система пасового типу найбільш універсальна. Пасові транспортери вдало поєднується із безупинними способами обрізування книжкових блоків з трьох боків. $€$ декілька варіантів побудови пасових транспортерів, які мають свої переваги та недоліки.

у випадку, коли пас транспортера переміщується і базується на опорних роликах, транспортування затиснутого блока супроводжується деформацією у контактуючих площинах. Місцева деформація виникає внаслідок характерних чинників:

- зміни сумарної сили різання;

- жорсткості паса; ня КЖБ;

- швидкості транспортуван-

- фізико-механічних властивостей паперу, з якого виготовлений блок та його геометричних розмірів;

- зусилля затиску блока.

Під час прогину паса між роликами утворюються зони технологічно недостатнього затис- кування блоків. Це суттєво зменшує технологічні показники якості виробу. Особливо, під час проходження з однієї блокообробної секції до іншої.

Використання транспортнопередавального пристрою, в якому пас ковзає по напрямних, має наступні конструктивні особливості. Контактуючі поверхні пасового транспортера і його напрямної вкриваються шаром антифрикційного матеріалу. Також покривається антифрикційним матеріалом площина, що взаємодіє з блоком. При обрізуванні блоків товщиною $\mathrm{H} \geq 25$ мм спостерігається нагрівання контактуючих поверхонь пасів і напрямних внаслідок тертя.

Нагрівання відбувається внаслідок того, що площини пасового транспортера забезпечують не тільки переміщення блоків, a і необхідне зусилля ї затиску. Зменшення сил тертя досягається за рахунок системи пневмопіддуву паса. Конструктивно пневмопіддув спрацьовує, коли блок знаходиться в його зоні.

В транспортно-передавальних пристроях, не допускається будь яке зміщення блока відносно напрямку його руху. Тому пристрої повинні забезпечувати необхідне технологічне зусилля затиску блока $\mathrm{P}_{\text {зат }}=\mathrm{P}_{\mathrm{Tp}} / \mathrm{f}$, де $\mathrm{P}_{\text {тр }}$ - зусилля транспортування блока; $f$ - коефіцієнт тертя між блоком і пасами транспортера.

Зусилля затиску блока залежить від властивостей паперу, 3 якого він виготовлений, максимальних значень складових сил різання та способу подачі КЖБ в різальну секцію. 


\section{Висновки}

У статті розглянуті основні способи і засоби транспортування книжкових і журнальних блоків в потоковому виробництві. Проведено порівняльний аналіз виконавчих механізмів пристроїв, які забезпечують зміну напрямку руху або перебазування книжково-журнальних блоків. Вказані технологічні операції можуть відбуватися під час вистою напівфабрикату так і під час його транспортування. Було встановлено, що безупинна обробка книжково-журнальних блоків в потокових лініях суттєво підвищує продуктивність брошурувально-палітурного виробництва.

Підсумовуючи швидкісні характеристики транспортно-передавальних пристроїв, зокрема механізмів перебазування блоків, зміни їх напрямку руху необхідно відмітити, що важливим показником якості виконання кожної технологічної операції обробки блока є якісне базування напівфабрикатів та їх вирівнювання $з$ двох боків.

Пасові транспортно-передавальні пристрої мають ряд переваг. Конструктивні особливості пасової стрічки дозволяють вільно їй рухатися по напрямних, які унеможливлюють виникнення поперечних коливань. Крім того напрямні створюють опору і необхідне зусилля затиску блоків.

Синхронізація руху проміжкових транспортерів і кареток пристроїв перебазування книжкових блоків може бути забезпечена, лише у випадку застосування спільного привода машини.

1. Хведчин Ю. Й. Брошурувально-палітурне устаткування. Ч. 2: Палітурне устаткування. Підручник / Ю. Й. Хведчин. - Львів : УАД, 2007. - 392 с. 2. Пергамент Д. А. Брошюровочно-переплетное оборудование / Д. А. Пергамент. - М. : МПИ, 1990. - 452 с. 3. Топольницький П. В. Нові технології та пристрої для різання поліграфічних матеріалів та книжково-журнальних блоків : навч. посіб. / П. В. Топольницький, О. Б. Книш. - Львів : Афіша, 2003. - 88 с. 4. Топольницький П. В. Пристрої для зміни напрямку руху поліграфічних напівфабрикатів у багатопозиційних машинах та потокових лініях / П. В. Топольницький, Р. Б. Стахів // Друкарство. — 2002. - № 3(44). С. 54-55. 5. Стахів Р. Б. Пристрій для перебазування книжкових блоків в автоматичних лініях / Р. Б. Стахів // Поліграфія і видавнича справа. 1999. - № 35. - С. 14-18. 6. Полюдов О. М. Механіка поліграфічних і пакувальних машин : навч. посіб. / О. М. Полюдов. - Львів : УАД, 2005. - 177 с. 